\title{
Redactioneel
}

\section{Akkoorden aanpak en toezicht}

\author{
Martijn Groenleer*
}

Ruim vijf jaar geleden schreven we op deze plaats naar anleiding van het regeerakkoord van het kabinet RutteII het volgende:

'Vermindering van de toezichtslasten voor degenen die onder overheidstoezicht vallen, en de kosten van de rijksoverheid lijken (opnieuw) de enige ambities te zijn. Immers, geen woord in het regeerakkoord over hoe de coalitiepartijen denken dat toezicht beter kan bijdragen aan de bescherming van vitale maatschappelijke belangen als veiligheid, gezondheid en eerlijke concurrentieverhoudingen en het voorkomen van hoge maatschappelijke kosten door niet-naleving. Evenmin wordt iets gezegd over herstel van het vertrouwen van burgers, ondernemingen en maatschappelijke organisaties in de overheid als toezichthouder.'

Wie had gehoopt dat het kabinet Rutte-III met een vernieuwende visie op toezicht zou komen zal (wederom) teleurgesteld zijn. Net als door voorgaande kabinetten wordt toezicht door het kabinet Rutte-III vooral gezien als een last voor bedrijven en een kostenpost voor de overheid - lasten en kosten die moeten worden verminderd. Geen sectoroverstijgende plannen voor het verbeteren van het overheidstoezicht op de naleving van regels. Toch zou dit regeerakkoord, zoals we hieronder uiteenzetten, wel eens belangrijke implicaties kunnen hebben voor toezicht, juist waar het niet expliciet rept over toezicht.

In het regeerakkoord vinden we allereerst de - gebruikelijke - voorstellen voor het schrappen of aanpassen van regels. Naar aanleiding van een pilot met 'regelluwe scholen' gaat het kabinet bijvoorbeeld sommige landelij-

Prof. dr. M.L.P. Groenleer is hoogleraar recht en bestuur aan Tilburg University en directeur van het Tilburg Center for Regional Law and Governance (TiREG). ke regels voor scholen schrappen en in het verlengde hiervan de sector stimuleren om de eigen administratieve regeldruk terug te dringen. In het sociale domein worden zogenaamde 'schrapsessies' georganiseerd met zorgaanbieders, zorgverleners, verzekeraars, gemeenten en toezichthouders, gericht op minder bureaucratie en minder regels. Het kabinet gaat ook inventariseren welke knelpunten in regelgeving, toezicht en handhaving duurzame innovaties op weg naar een circulaire economie in de weg staan en hoe die mogelijk opgelost kunnen worden. En mededingingsregels moeten worden aangepast als samenwerking in het belang van patiënten door die regels wordt gefrustreerd.

In het regeerakkoord benadrukt het kabinet daarnaast dat het toezicht beter moet worden georganiseerd. Om de administratieve en toezichtslasten te verminderen moeten de diverse inspecties 'beter' gaan samenwerken - zonder overigens verder in te gaan op hoe dit dan precies zou moeten. En er moet 'passend' toezicht komen voor de verschillende proefprojecten, experimenteerruimtes, testlocaties en regelvrije zones die het kabinet voorstelt of mogelijk wil maken. Om te voorkomen dat mensenhandelaren profiteren van ongelijke toezichts- en handhavingsmogelijkheden wordt het wetsvoorstel Regulering prostitutie aangepast. De onderwijsinspectie, ten slotte, krijgt meer ruimte om bij de beoordeling van scholen rekening te kunnen houden met de eventuele aanwezigheid van bovenmatig veel zorgleerlingen.

Tegelijkertijd doet het kabinet voorstellen voor meer toezicht. Om ervoor te zorgen dat middelen voor passend onderwijs in de klas terechtkomen, komt er onafhankelijk toezicht op de samenwerkingsverbanden voor passend onderwijs. Het kabinet gaat de trustsector in Nederland strengere regels opleggen, en De Nederlandsche Bank krijgt meer bevoegdheden voor toezicht en handhaving op dergelijke regels. Om het dierenwelzijn en de voedselveiligheid te garanderen en de reputatie van de Nederlandse agro-foodsector te beschermen, 
wordt het toezicht aangescherpt. Mocht uit een evaluatie van de nieuwe Wet op de inlichtingen- en veiligheidsdiensten blijken dat de rechten van individuele burgers onvoldoende zijn gewaarborgd, dan zal het kabinet voorstellen doen voor additionele waarborgen en versterking van het toezicht.

Verder maakt het kabinet extra geld vrij voor toezicht. $\mathrm{Zo}$ is er 50 miljoen euro voor de handhavingsketen van de Inspectie SZW, om beter toezicht te houden op het wettelijk minimumloon en om intensiever schijnconstructies, onveilige en ongezonde arbeidsomstandigheden en uitbuiting tegen te gaan. Voor versterking van de geplaagde Nederlandse Voedsel- en Warenautoriteit (NVWA) organisatie is jaarlijks extra geld beschikbaar, tot 20 miljoen euro structureel an het einde van de kabinetsperiode.

De mogelijk belangrijkste gevolgen van het regeerakkoord, ook voor het toezicht, zijn evenwel van andere aard. Het kabinet zet in op het sluiten van een groot antal akkoorden op verschillende thema's, van energie tot sport en asiel, met uiteenlopende partijen, waaronder scholen, woningcorporaties, steden en regio's. Gegeven de fragmentatie van de politiek en de pluriformiteit van de samenleving is deze aanpak goed te begrijpen, en natuurlijk ook niet nieuw. Besluitvorming en wetgeving in klassieke zin passen nu eenmaal niet zo goed bij een complexe en dynamische werkelijkheid. Het maken van gerichte afspraken over maatschappelijke vraagstukken met direct betrokken groepen kan zowel de effectiviteit als de legitimiteit van de oplossingen ten goede komen.

Aan deze aanpak kleven ook belangrijke risico's, niet in de laatste plaats vanuit het perspectief van toezicht. Omdat het meestal niet (direct) gaat om wet- en regelgeving, is de vraag hoe handhaving kan worden georganiseerd en hoe naleving kan worden gegarandeerd. Wie houdt er (legitiem) toezicht op de uitvoering van deze akkoorden, als daar geen wetten of regels aan te pas komen? Bovendien: we weten dat het traditionele toezicht niet altijd even effectief is, maar wie zegt ons dat deze akkoorden niet zullen sneven in vrijblijvendheid en opportunisme?

We pleiten hier niet voor het negeren van de ingewikkelde sturingsvraagstukken waar beleidsmakers en toezichthouders zich vandaag de dag voor geplaatst zien, noch voor het herstellen van de klassieke rol van 'Den Haag' in een steeds verder geglokaliseerde samenleving. Integendeel, we vragen hier aandacht voor de innovaties die nodig zijn in het toezicht met het oog op het met elkaar in overeenstemming brengen van effectiviteit en legitimiteit, van inhoud en proces, van slagvaardigheid en bedachtzaamheid. Genoemde akkoorden vereisen nieuwe (of in ieder geval alternatieve) bestuurlijke en juridische instrumenten en methodieken, rollen en verantwoordelijkheden, zeker ook voor toezichthouders, inspecties en handhavers. Daar ligt, wat ons betreft, een belangrijke uitdaging voor het toezicht in de komende jaren.

Het artikel van Schakel \& Stoopendaal, over de plaats van intern toezicht in de praktijk van extern toezicht, sluit aan bij ons pleidooi. Juist als een grotere rol is weg- gelegd voor allerlei private en maatschappelijke organisaties bij het maken van 'soft law'-afspraken, zoals in de zorg, het onderwijs en in de woonsector, is het van belang dat de interne governance van dat soort organisaties op orde is, en dat het interne toezicht op die governance het externe toezicht aanvult en versterkt. Schakel \& Stoopendaal laten zien dat de verwachtingen in de wetenschappelijke en beleidsliteratuur over de aanvullende en versterkende werking van het interne toezicht hoog zijn. De ervaringen in de praktijk blijken echter beperkt. Er is volgens de auteurs nauwelijks sprake van interactie tussen interne en externe toezichthouders. Onduidelijk is daarom ook of er sprake is van aanvulling en versterking. Waar er al wel ervaringen zijn, zoals in het toezicht op financiële markten, kunnen die wellicht ter inspiratie dienen voor andere sectoren, zo suggereren Schakel \& Stoopendaal.

Spronk et al. doen verslag van de lessen die zij binnen de Inspectie Gezondheidszorg en Jeugd hebben opgedaan met de ontwikkeling van een 'afwegingskader vertrouwen'. Het begrip vertrouwen, ook centraal in het regeerakkoord, is inmiddels niet meer weg te denken uit het toezichtsvocabulaire. In de praktijk blijkt het niet zo eenvoudig hieraan handen en voeten te geven: waarop kunnen inspecteurs het vertrouwen in een ondertoezichtgestelde baseren? Het artikel voorziet in praktische handvatten voor inspecties en toezichthouders.

In een opiniërend tweeluik gaan Ira Helsloot en Frits Meijer in op het wetsvoorstel voor gedeeltelijke privatisering van het bouwtoezicht in Nederland. Helsloot is helder: een gereguleerde markt kan beter zelf toezicht houden. Het wetsvoorstel is een stapje in de goede richting maar niet per se een stap vooruit. De discussie die, volgens Helsloot, gevoerd had moeten worden, over hoe private toetsing op de bouwkwaliteit vorm te geven, is niet gevoerd. Meijer is ook positief over privaat toezicht, maar opteert voor een oplossing in het midden: een hybride of zelfs duaal stelsel, mede omdat er serieuze vragen kunnen worden gesteld over de onafhankelijkheid, aansprakelijkheid en verzekerbaarheid van private toetsers.

De column van Judith van Erp richt zich op de relatie tussen toezicht en wetenschap naar aanleiding van het emeritaat van twee exemplarische trait d'unions: Paul Robben en Henk van de Bunt. Volgens Van Erp is de belangrijkste bijdrage die beide hoogleraren hebben geleverd gelegen in de relevantie van hun werk voor de toezichtspraktijk. Een dergelijke bijdrage is niet langer evident in een steeds meer door citatiescores en impactfactoren gedomineerde wetenschap. Ze pleit daarom voor een verbetering van de vertaalslag van wetenschap naar praktijk en vice versa. De wetenschapsagenda toezicht waartoe de Inspectieraad het initiatief heeft genomen, kan daarbij een rol spelen.

De titel van het boek dat Anna Marhold bespreekt, Regulatory Theory: Foundations and Applications, is niet de meest aansprekende, zeker niet voor de gemiddelde toezichtsprofessional. Toch is juist dit boek - gratis te downloaden! - een uitstekend voorbeeld van een academisch werk dat de brug probeert te slaan naar de toe- 
zichtspraktijk. Met een keur aan wetenschappers én professionals, velen van hen betrokken bij het Australische netwerk voor toezicht (RegNet), die hun licht laten schijnen over een veelheid aan fundamentele en praktische thema's, slaagt dit boek er volgens Marhold in een actiegericht overzicht te geven van de state-of-the-art in het toezichtsonderzoek.

Toezichthouders leggen regelmatig (hoge) bestuurlijke boetes op. Aan welke bewijsrechtelijke maatstaven moeten zij eigenlijk voldoen? Ymre Schuurmans beantwoordt deze vraag in haar notenkraker naar aanleiding van een uitspraak van de Afdeling bestuursrechtspraak van de Raad van State in de zogenaamde Cruiseschepenboumers-zaak, over het vergaren van bewijs in boetezaken. Deze uitspraak geeft vooral voor getuigenbewijs vrij precieze regels en verkleint de ruimte van de toezichthouder voor nadere bewijslevering in beroep, aldus Schuurmans.

In zijn notenkraker gaat Arnt Mein in op een andere vraag die het opleggen van boetes oproept: hoe transparant moet een toezichthouder zijn over haar boetetoemetingsbeleid? Transparantie zou immers ten koste kunnen gaan van de effectiviteit van het toezicht. In een uitspraak over het boetetoemetingsbeleid van de AFM dwingt het College van Beroep voor het bedrijfsleven $(\mathrm{CBb})$ de AFM haar (interne) beleid openbaar te maken. Ze rekent de AFM vervolgens af volgens dat beleid en komt tot het oordeel dat de boete verder moet worden gematigd. De notenkrakers van zowel Schuurmans als Mein laten zien dat de rechter het opleggen van boetes door inspecties en toezichthouders kritisch toetst en niet aarzelt tegenwicht te bieden als zij van oordeel is dat de rechtsbescherming van ondertoezichtgestelden in het geding is.

We vragen, tot slot, graag aandacht voor de 'Call for papers' voor het $T v T$ themanummer over toezicht en (big) data. Door digitalisering neemt de hoeveelheid verzamelde data razendsnel toe. Wat zijn de implicaties voor toezicht, in termen van verantwoorde toegang en gebruik, en maatschappelijke waardecreatie? 